\title{
Planting Plan for Flower Border based on the Flowering Period and Plant Height of Perennial Herbaceous Garden Plants in the Middle Part of Korea
}

\author{
Kwanhwa Sohn* \\ Gardening Course, Dept. of Smart Horitculture, Yonam College, Seonghwan 31005, South Korea
}

\begin{abstract}
This study was carried out to present basic planting plans for the flower borders which are flowering all year round in the middle part of Korea. Flowering periods and plant heights of herbaceous in Hantaek Botanical Garden, Mulhyanggi Arboretum, and Yonam College were investigated from 2013 to 2014. The number of species of perennial which were flowering more than one month was 387 species, $278(71.8 \%)$ in Hantaek, $81(20.9 \%)$ in Mulhyanggi, and $28(7.2 \%)$ in Yonam. The number of species of white perennial was $85(22.0 \%)$, yellow 79 (20.4\%), purple $73(18.9 \%)$, pink $72(18.6 \%)$, blue $35(9.0 \%)$, red $18(4.7 \%)$, orange $18(4.7 \%)$, and green 7 (1.8\%). The number of species of perennial with large plant (above $120 \mathrm{~cm})$ was $56(14.5 \%)$, medium $(60-120 \mathrm{~cm})$ $99(25.6 \%)$, and small (below $60 \mathrm{~cm}) 232(59.9 \%)$. In order to propose the planting plan., $10 \mathrm{~m} \times 3 \mathrm{~m}$ flower borders were derived from the reference and the photos taken on visits. The flowers of the perennials were grouped into eight groups based on flower color, and the six flower border layouts with colors of white, yellow, violet, pink, red \& orange, and blue \& green were presented. Each flower border was divided into $1 \mathrm{~m} \times 1 \mathrm{~m}$ unit area and plants of same species were randomly placed in each unit area with large plants in the back, medium plants in the middle, and small plants toward the front of border. Each kind of perennial with different flowering period was arranged randomly to achieve continuous blooms throughout the year. Flower borders with white, yellow, purple and pink flowers are arranged facing the flower border with the same color on the opposite side of path.
\end{abstract}

Keywords: flower bed, flower color, flower garden, garden design, gardening

\section{Introduction}

As people's interest in gardens has grown in South Korea, their interest in the design of planting herbaceous flowering plants that can color and give changes to gardens has also increased. Herbaceous flowering plants are widely used in gardens in various forms and for various purposes such as low-growing plants under garden trees, ground-cover plants, flowerpots, flower beds and borders, etc. (Sohn, 2012, 2013). In particular, herbaceous flowering plants are used mostly to create flower beds and borders, and their colors make them more bright and colorful (Billington, 2002; Bisgrove, 1992; Jekyll, 2001; Young, 2009). There are many ways to create flower beds and borders, but plant height, flower color and flowering period are mainly considered in planting herbaceous flowering plants from a visual perspective along with other

Received: February 14, 2018, Revised: April 11, 2018, Accepted: April 11, 2018

First author: Kwanhwa Sohn, E-mail: khsohn@yonam.ac.kr, ORCID: 0000-0002-5855-700X

*Corresponding author: Kwanhwa Sohn, E-mail: khsohn@yonam.ac.kr, ORCID: 0000-0002-5855-700X 
elements such as shape, planting interval, and texture (Brickell, 2007; Lord and Lawson, 2008; Park and Yoo, 2011; Sohn, 2012).

Garden designers research relevant materials and websites that they can refer to when designing flower beds and borders and gardens. In the floriculture market, however, sufficient data about the flowering period and plant height of both existing and new varieties are not available. While their adaptability to domestic soil and climate environments have not been sufficiently proved, a number of new and foreign varieties have been rapidly introduced, shipped and distributed annually. Those that fail to adapt to domestic environments or are not used in the domestic market often disappear from the market. For this reason, garden designers research the floriculture market before designing gardens, but planting designs are often altered in the process of creating actual gardens. In addition, since the flowering of most herbaceous flowering plants is controlled before being circulated in the market, they often flower more rapidly or slowly than their original flowering period. After herbaceous flowering plants purchased from the market, and, in particular, herbaceous perennials are planted in gardens, most of them tend to flower in different times in the next year, and thus planting plans can easily go wrong without sufficient knowledge or information about herbaceous flowering plants.

Those that grow seasonally are susceptible to the macroclimate of regions as well as the microclimate of cities, and thus even the same varieties and regions show different flowering periods depending on the altitude and slope of the ground and the location of branches (Jo and Ahn, 2008). Herbaceous perennials planted in gardens show slightly different flowering periods annually in the climatic environment of Korea, but sufficient data about the flowering period of herbaceous perennials used in gardens must be established for planting designs. Against this backdrop, in this study, the flowering period and plant height of herbaceous perennials that flower in the central region of Korea were surveyed, and the surveyed perennials were divided into 8 flower colors and 3 plant heights (Brickell, 2002; Sohn, 2012) in order to suggest basic planting plans for creating flower beds or borders with year-round flowering plants (Rice, 2006).

\section{Research Methods}

Gardens in the central region where many herbaceous flowering plants are planted were selected, and their flowering period and plant height were surveyed. Methods to create flower beds or borders that are widely used in other countries were also analyzed. Among the surveyed herbaceous flowering plants, herbaceous perennials that flower for over one month were selected and basic flower borders were suggested based on their flowering period and plant height by flower color.

\section{Survey on the size of flower beds and borders}

A flower bed is '꽃밭’ in Korean and ‘花壇' in Chinese. Among many types of flower beds, those that are stretched along walls are called a 'flower border' which is widely used in other countries (Park, 2010b). Flower beds and borders can be created in different sizes and shapes, but, in this study, methods that are widely used in specialized gardens where many herbaceous flowering plants are planted were surveyed in order to determine a proper size of flower beds and borders where the perennials suggested in this study can be planted. Related documents (Brickell, 2007; Brickell, 2010; Brickell and Cathey, 2004; Lord and Lawson, 2008; Oudolf and Kingsbury, 2017; Park, 2010b; Rice, 2006) and photos taken in gardens that were personally visited in Korea and abroad were analyzed.

\section{Flowering period and plant height of herbaceous flowering perennials}

This study was conducted from January, 2013 to December, 2014 in three places: Hantaek Botanical Garden in 
Gyeonggido which is known to have the highest number of herbaceous flowering plants in Korea (a total of 9,700 plants, 7,300 imported plants, 1,700 native herbaceous plants, 660 overwintering perennials in the central region); Mulhyanggi Arboretum where many herbaceous flowering plants are planted within a range that can be surveyed; and a garden in Yonam College in Chungcheongnam-do near Gyeonggi-do (Table 1). The flowering period and plant height of herbaceous
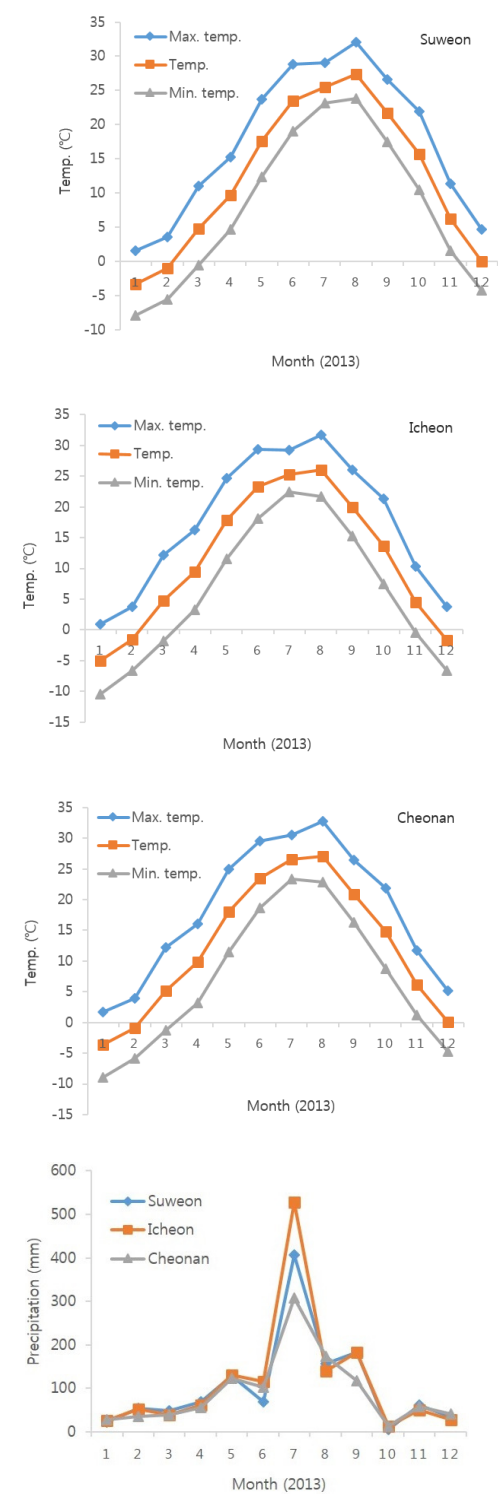
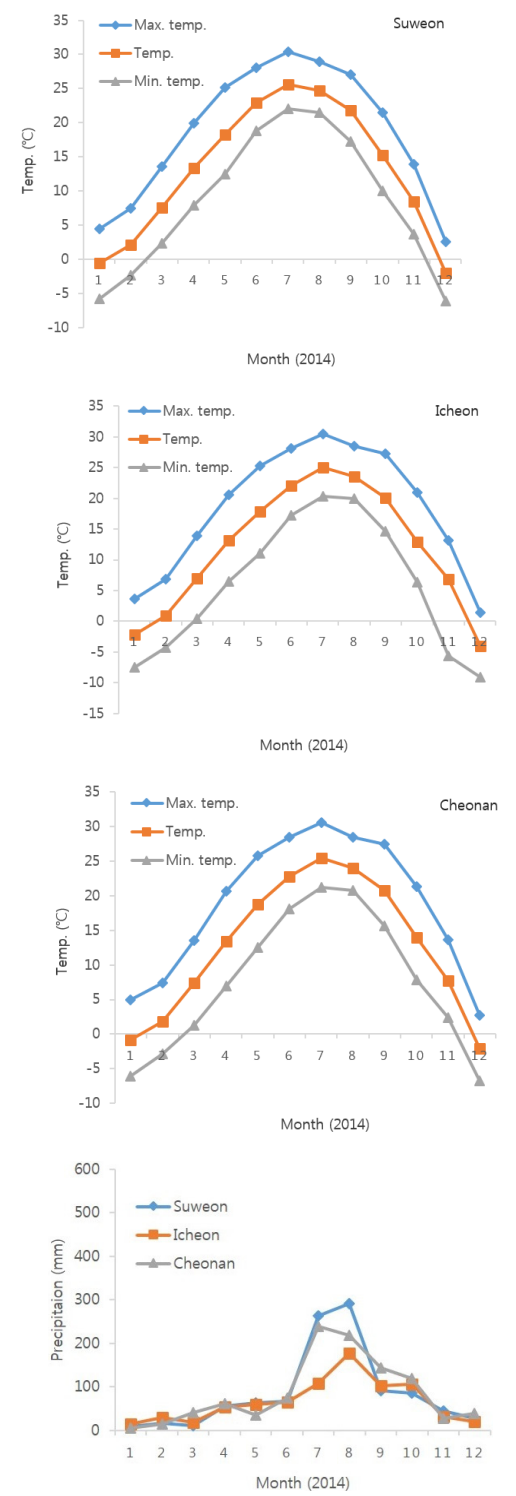

Figure 1. Monthly temperature and precipitation at three nearest meteorological stations (Suweon, Icheon, and Cheonan) respectively to Hantaek Botanical Garden, Mulhyanggi Arboretum, and Yonam College from 2013 to 2014. The data were from Korea Meteorological Administration.

Table 1. The location of three places where flowering periods and plant heights of herbaceous perennial garden plants were investigated

\begin{tabular}{|c|c|c|c|}
\hline Place of investigation & Hantaek Botanical Garden (HBC) & Mulhyanggi Arboretum (MA) & Yonam College (YC) \\
\hline \multirow{2}{*}{ Latitude \& Longitude } & N37.09 & N37.17 & N36.95 \\
\hline & E127.41 & E127.06 & E127.16 \\
\hline Distance from Yonam College & $30.56 \mathrm{~km}$ & $35.80 \mathrm{~km}$ & $0 \mathrm{~km}$ \\
\hline
\end{tabular}


flowering perennials planted in the three surveyed places. Since the survey was conducted once every 10 days, it was difficult to cover more places in this study. The survey was conducted on the 5th, 15th and 25th of every month in 2013, and they were surveyed again on the 15 th of every month in 2014. The average, maximum and minimum temperature and precipitation measured in three meteorological stations in Suwon, Icheon and Cheonan near the three gardens within the survey period are as shown in Fig. 1.

Changes in the flowering period of flowers depending on their characteristics were surveyed as follows. Herbaceous flowering plants that grow in colonies in the selected gardens (Brickell, 2007; Brickell and Cathey, 2004; Rice, 2006) were surveyed since multiple flowers flower from a single plant in most cases. In the case of a single flower, the time when a flower bud starts to open and show $20 \%$ of its flower color was regarded as the beginning of flowering, and the time when over $80 \%$ of floral leaves wither was regarded as the end of flowering. In the case of those planted in groups, the time when the flower buds of over $20 \%$ of the entire flowers start to open and show flower color was regarded as the beginning of flowering, and the time when over $80 \%$ of the entire flowers wither was regarded as the end of flowering.

Plants were divided into 9 flower colors based on the criteria for herbaceous flowering plants, and was divided into three plant heights (large: over $120 \mathrm{~cm}$, medium: $60-120 \mathrm{~cm}$, small: less than $60 \mathrm{~cm}$ ) based on the criteria for measuring the plant height of herbaceous perennials, instead of measuring it specifically (Brickell, 2002; Brickell, 2010; Sohn, 2012, 2013).

\section{Suggesting flower border planting plans for herbaceous flowering perennials by flower color}

In order to highlight the relationship with plant height, flower borders (length $10 \mathrm{~m} \times$ width $3 \mathrm{~m}$ ) were suggested among various types of flower beds in this study. When creating flower borders, plant height is significantly considered. Herbaceous perennials that were found to flower over one month were selected for the suggested flower borders (Park, 2010a). Since there were many species of perennials surveyed in this study, they were divided into 9 colors based on the criteria for herbaceous flowering plants. In particular, there were many perennials with white, yellow, pink and violet flowers, and thus they were laid out along the two flower borders created on both sides of a road (the width of the road was not determined). Only few perennials with red and orange flowers were observed, and thus they were arranged opposite to each other. Those with blue and green flowers were also arranged opposite to each other. Since silver is a color of leaves, those with silver flowers were excluded from this study.

\section{Results and Discussion}

\section{Size of flower beds and borders}

Flower beds can be freely created in different shapes such as circle, rectangle and arabesque and planted with herbaceous flowering plants of a different or equal length. However, flower borders are called '경재화단 (meaning bordered flower bed)' or '살피꽃밭 (roadside flower garden)' in Korean, and, in many cases, they are created along walls to be seen from one direction. Mostly small plants are planted in the front row and large plants are planted in the back row (Lord and Lawson, 2008; Rice, 2006) (Fig. 2). Flower borders can be created in different sizes and a proper size can be determined while planting and managing flowers. Well-created flower borders are planted with plants of three different sizes (small, medium, large): small plants in the front row, medium plants in the second row and large plants in the last row. In general, the width of flower borders is two times the height of the tallest plant, having an elegant ratio (Brickell, 2007; Lord and Lawson, 2008; Rice, 2006). Large borders can be created using large perennials. However, since stems as well as flowers need to look beautiful, the height of large plants needs to be maintained lower than $1.5 \mathrm{~m}$ (Brickell, 2007). 


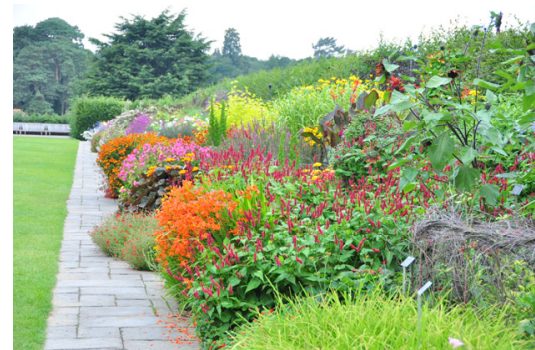

Flower border in Wisley Garden, United Kingdom

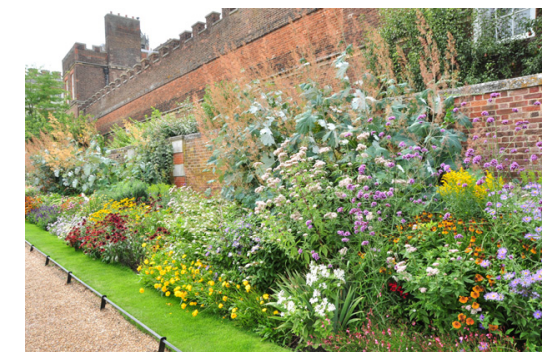

Flower border in Hampton Court Palace, United Kingdom

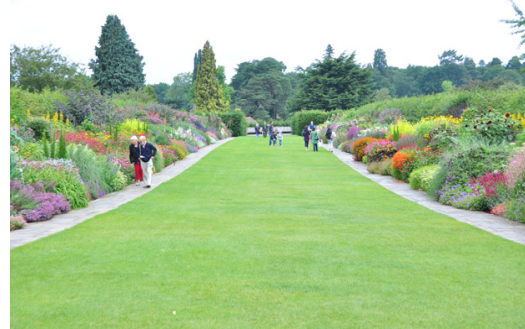

Flower border on both sides of the path in Wisley Garden, United Kingdom

Figure 2. Flower beds and borders in United Kingdom.

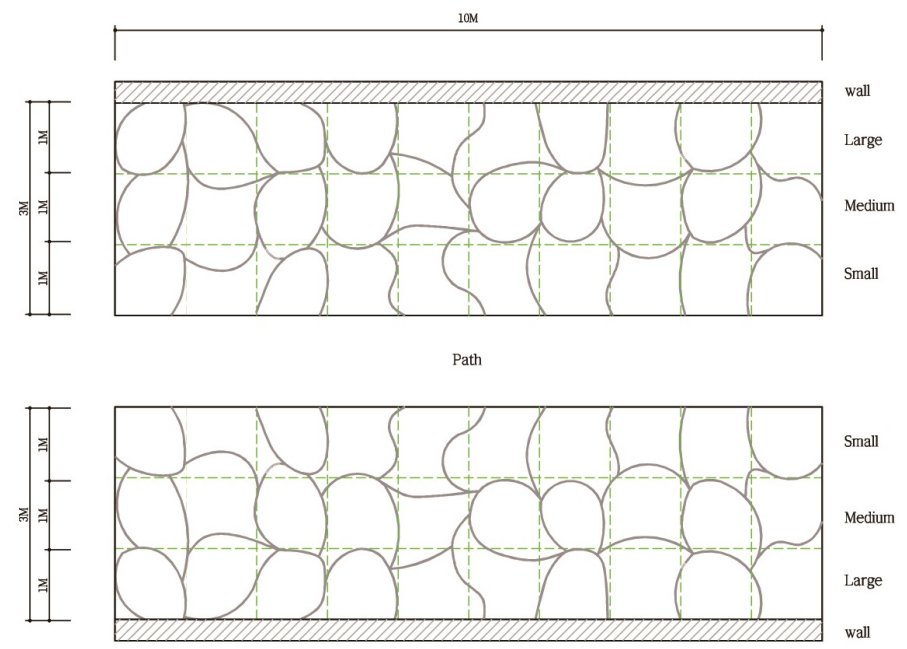

Figure 3. The flower borders presented for this study. The width of path is not fixed.

It is convenient to maintain plants and hedges using a passage created in the back of flower borders, but if there is not enough space available, it can be excluded.

Herbaceous flowering plants used in flower beds or borders are planted in groups either in a lattice pattern or in odd numbers in a natural and irregular way. These plant groups planted in tiers in front of flower borders are called 'drift' in other countries as they look like floating flowers on the water. When plating flowers in drifts, the recommended width of flower borders is mostly $3 \mathrm{~m}-4 \mathrm{~m}$, and the same plant groups are arranged repeatedly at intervals in order to give a feeling of unity to long borders (Brickell, 2007; Brickell, 2010; Brickell and Cathey, 2004; Oudolf and Kingsbury, 2017).

Based on these guidelines, the width of flower borders in this study was set to be $3 \mathrm{~m}$ for suggesting plans for planting herbaceous perennials for gardens. The length of flower borders can be freely decided by laying out the same plant groups repeatedly at intervals. The number of flowers observed in this study was different depending on their color, but the length of flower borders was planned to be $10 \mathrm{~m}$ in order to fully utilize perennials with white, yellow, pink and purple flowers that were found in large quantities. Flower borders were arranged on both sides of a road. The width of the road can be adjusted depending on the length of flower borders (Figs. 2 and 3).

\section{Flowering period and plant height of herbaceous flowering perennials}

Flowering plants have a certain period of flowering but the period can slightly differ annually depending on the climate conditions of the year. Winter in January in 2013, when this study was initiated was much colder than other years, and thus 
the growth period of herbaceous flowering perennials that grow well in warm temperatures was reduced due to the severe cold in the winter. The changes were observed with the naked eye.

General gardens in houses can be planted with various herbaceous flowering plants that flower for less than one month, but in the case of flower beds or borders in commercial gardens or parks, it is inconvenient to manage herbaceous flowering plants that flower for less than one month. The three places selected in this study were visited on the 5th, 15th and 25th of every month, and 387 herbaceous perennials were found to flower for over one month (Table 2). The number of herbaceous perennials planted in Hantaek Botanical Garden was the highest. Those that were not found in Hantaek

Table 2. Monthly number of perennial herbaceous garden plants which are flowering more than one month in three places (Hantaek Botanical Garden, Mulhyanggi Arboretum and Yonam College) in 2013 and 2014 based on flower color and plant height

\begin{tabular}{|c|c|c|c|c|c|c|c|c|c|c|c|c|c|c|c|}
\hline \multirow{2}{*}{$\begin{array}{c}\text { Flower } \\
\text { color }\end{array}$} & \multirow{2}{*}{$\begin{array}{c}\text { Plant } \\
\text { height }^{\mathrm{z}}\end{array}$} & \multicolumn{12}{|c|}{ Number of monthly flowering plants } & \multirow{2}{*}{$\begin{array}{c}\text { Total No. } \\
\text { of monthly } \\
\text { flowering } \\
\text { plants }\end{array}$} & \multirow{2}{*}{$\begin{array}{c}\text { No. of } \\
\text { flowering } \\
\text { plant } \\
\text { species }\end{array}$} \\
\hline & & Jan. & Feb. & March & April & May & June & July & Aug. & Sept. & Oct. & Nov. & Dec. & & \\
\hline \multirow{3}{*}{ White } & $\mathrm{L}$ & 0 & 0 & 0 & 0 & 1 & 3 & 6 & 6 & 3 & 2 & 0 & 0 & 21 & 10 \\
\hline & M & 0 & 0 & 0 & 0 & 6 & 15 & 13 & 10 & 11 & 6 & 1 & 0 & 62 & 29 \\
\hline & $\mathrm{S}$ & 0 & 0 & 3 & 14 & 23 & 20 & 9 & 5 & 9 & 6 & 3 & 0 & 92 & 46 \\
\hline \multirow{3}{*}{ Yellow } & $\mathrm{L}$ & 0 & 0 & 0 & 0 & 1 & 5 & 15 & 11 & 5 & 3 & 1 & 0 & 41 & 18 \\
\hline & M & 0 & 0 & 0 & 0 & 2 & 12 & 9 & 0 & 1 & 2 & 1 & 0 & 27 & 14 \\
\hline & $\mathrm{S}$ & 0 & 0 & 5 & 17 & 23 & 20 & 18 & 9 & 6 & 7 & 3 & 2 & 110 & 47 \\
\hline \multirow{3}{*}{ Purple } & $\mathrm{L}$ & 0 & 0 & 0 & 0 & 2 & 6 & 8 & 6 & 6 & 3 & 1 & 0 & 32 & 13 \\
\hline & M & 0 & 0 & 0 & 0 & 5 & 5 & 3 & 6 & 6 & 2 & 0 & 0 & 27 & 13 \\
\hline & $\mathrm{S}$ & 0 & 2 & 12 & 18 & 17 & 13 & 10 & 11 & 8 & 3 & 0 & 0 & 94 & 47 \\
\hline \multirow{3}{*}{ Pink } & $\mathrm{L}$ & 0 & 0 & 0 & 0 & 1 & 5 & 6 & 2 & 3 & 1 & 0 & 0 & 18 & 8 \\
\hline & M & 0 & 0 & 0 & 0 & 3 & 14 & 12 & 7 & 6 & 1 & 1 & 0 & 44 & 20 \\
\hline & $\mathrm{S}$ & 0 & 0 & 1 & 12 & 18 & 19 & 8 & 7 & 14 & 11 & 5 & 0 & 95 & 44 \\
\hline \multirow{3}{*}{ Red } & $\mathrm{L}$ & 0 & 0 & 0 & 0 & 0 & 0 & 0 & 1 & 1 & 0 & 0 & 0 & 2 & 1 \\
\hline & M & 0 & 0 & 0 & 0 & 0 & 4 & 4 & 1 & 1 & 0 & 0 & 0 & 10 & 5 \\
\hline & $\mathrm{S}$ & 0 & 0 & 3 & 5 & 6 & 5 & 1 & 4 & 3 & 1 & 0 & 0 & 28 & 12 \\
\hline \multirow{3}{*}{ Orange } & $\mathrm{L}$ & 0 & 0 & 0 & 0 & 0 & 0 & 2 & 2 & 0 & 0 & 0 & 0 & 4 & 2 \\
\hline & M & 0 & 0 & 0 & 0 & 0 & 2 & 4 & 3 & 2 & 0 & 0 & 0 & 11 & 7 \\
\hline & S & 0 & 0 & 0 & 2 & 3 & 4 & 5 & 1 & 0 & 1 & 1 & 0 & 17 & 9 \\
\hline \multirow{3}{*}{ Blue } & $\mathrm{L}$ & 0 & 0 & 0 & 0 & 1 & 2 & 1 & 2 & 2 & 0 & 0 & 0 & 8 & 4 \\
\hline & M & 0 & 0 & 0 & 0 & 2 & 6 & 5 & 4 & 3 & 1 & 0 & 0 & 21 & 9 \\
\hline & $\mathrm{S}$ & 0 & 0 & 1 & 9 & 15 & 6 & 0 & 0 & 2 & 1 & 0 & 0 & 34 & 22 \\
\hline \multirow{3}{*}{ Green } & $\mathrm{L}$ & 0 & 0 & 0 & 0 & 0 & 0 & 0 & 0 & 0 & 0 & 0 & 0 & 0 & 0 \\
\hline & M & 0 & 0 & 0 & 0 & 0 & 1 & 0 & 0 & 1 & 1 & 0 & 0 & 3 & 2 \\
\hline & S & 0 & 0 & 0 & 0 & 2 & 2 & 0 & 2 & 2 & 1 & 0 & 0 & 9 & 5 \\
\hline \multirow{5}{*}{ Total } & $\mathrm{L}$ & 0 & 0 & 0 & 0 & 6 & 21 & 38 & 30 & 20 & 9 & 2 & 0 & 126 & $56(14.5 \%)$ \\
\hline & M & 0 & 0 & 0 & 0 & 18 & 59 & 50 & 31 & 31 & 13 & 3 & 0 & 205 & $99(25.6 \%)$ \\
\hline & S & 0 & 2 & 25 & 77 & 107 & 89 & 51 & 39 & 44 & 31 & 12 & 2 & 479 & $232(59.9 \%)$ \\
\hline & Total & 0 & 2 & 25 & 77 & 131 & 169 & 139 & 100 & 95 & 53 & 17 & 2 & 810 & $387(100 \%)$ \\
\hline & Total & $(0.0 \%)$ & $(0.2 \%)$ & $(3.1 \%)$ & $(9.5 \%)$ & $(16.2 \%)$ & $(20.9 \%)$ & $(17.2 \%)$ & $(12.3 \%)$ & $(11.7 \%)$ & $(6.5 \%)$ & $(2.1 \%)$ & $(0.2 \%)$ & $(100 \%)$ & \\
\hline
\end{tabular}

${ }_{\mathrm{z}}^{\mathrm{z}}=$ large (above $\left.120 \mathrm{~cm}\right) ; \mathrm{M}=$ medium $(60-120 \mathrm{~cm})$; and $\mathrm{S}=$ small $($ below $60 \mathrm{~cm})$. 
Botanical Garden were included in this survey, and the perennials that flower in distinct colonies among those that were commonly planted in the three places were examined to measure their flowering period and plant height. The results found that, except 278 herbaceous perennials in Hantaek Botanical Garden, 81 and 28 herbaceous perennials that were additionally found in Mulhyanggi Arboretum and Yonam College respectively were included in this survey. Of the surveyed herbaceous perennials, many species and varieties were found under several genera such as Tuipa, Hosta, Astilbe, Aqulegia, Monarda, Iris, Hemerocallis, Lilium, Chrysanthemum, and Aster and were mixed in the gardens. For this reason, those that are well known were marked separately, and others were combined under the same genera or species to measure their quantity and overall flowering period. Aquatic plants and grasses that do not have a distinct flower color were excluded in this survey.

As Table 2 shows, the number of species of the following four colors was the highest: white, 85 species $(22.0 \%)$; yellow, 79 species (20.4\%); purple, 73 species (18.9\%); and pink, 72 species (18.6\%). The number of the species of blue, red, orange and green was $35(9.0 \%), 18(4.7 \%), 18(4.7 \%)$, and $7(1.8 \%)$ respectively. These results were similar to those of a study on the flower color of herbaceous perennials that major herbaceous perennial farms and botanical gardens in Korea have (Sohn, 2013). In addition, the number of plants of a plant height of over $120 \mathrm{~cm}$ was 56 , only $14.5 \%$ of the total surveyed plants, and that of plants of a medium height $(60-120 \mathrm{~cm})$ was $99(25.6 \%)$. The number of species of a plant height of less than $60 \mathrm{~cm}$ was 232 (59.9\%), accounting for a large share. In particular, there were many low-lying plants of a plant height of less than $20 \mathrm{~cm}$, and thus they are not suitable for flower beds or borders which require a certain height. Since the plant height of herbaceous flowering plants is highly susceptible to soil conditions, meteorological conditions such as sunlight, the height of the plants surveyed in this study does not always fall in the same category. In particular, the herbaceous perennials that have long adapted to the environment of Hantaek Botanical Garden were much taller than their height explained in illustrated plant books, and Eupatorium japonicum 'Gateway' and genera such as Rudbeckia and Silphium are as tall as $3 \mathrm{~m}$.

Flowering period was analyzed by month, and herbaceous perennials that flowered in June accounted for the largest share (20.9\%), followed by July (17.2\%), May (16.2\%), August (12.3\%), September (11.7\%), April (9.5\%), October (6.5\%), November $(2.1 \%)$, December $(0.2 \%)$, and February $(0.2 \%)$. Unlike the general perception that herbaceous flowering plants used in Korea mostly flower in Spring, they were found to continue to flower even until July, August and September. The results can be attributed to the fact that botanical gardens have both native and imported plants.

Flower beds or borders in other countries are created for one season in general (Brickell, 2007; Lord and Lawson, 2008), but it is very important to create flower borders by laying out various herbaceous perennials that flower in different months to ensure they flower throughout the year unless places are so spacious to disperse attractions (Lord and Lawson, 2008; Park, 2010a; Rice, 2006), especially in commercial gardens. However, even if flower borders that flower throughout the year are planned, there are only few plants that flower in January and February in the central region of Korea, and thus it is necessary to include evergreen perennials or give up visual effects in January and February. In order to overcome these problems, mixed flower beds that include woody plants have been increasingly used in other countries (Lord and Lawson, 2008; Rice, 2006). Mixed flower beds, however, also need to address several problems. Even if flower beds that flower throughout the year are planned as suggested in this study, it might be necessary to adjust visual effects using other methods in January and February.

As Table 2 shows, there are very few large perennials for gardens. Under the climate conditions of Korea, the rainy season and storms might affect the growth of plants, but large perennials make flower beds or borders very threedimensional and colorful (Oudolf and Kingsbury, 2005). Therefore, it will be necessary to find and develop large native plants suitable for flower beds or borders or to import other perennials. 


\section{Planting plans for herbaceous flowering perennials for flower borders by flower color}

In other countries, one flower species was planted in flower beds or borders in a lattice pattern repeatedly at intervals, but as the concept of flower color was introduced, flowers of similar or contrast colors have been laid out or various species of flowers of different colors have been planted along flower borders to create a spectrum effect. In doing so, the morphological characteristics of herbaceous flowering plants can be utilized and herbaceous plants with beautiful leaves can be planted together to adjust colors (Brickell and Cathey, 2004; Park, 2010b). Recently, shrubs such as lavender, rose and buddleja have been also included to give a sense of richness and change, and evergreen shrubs have been planted for visitors to enjoy in the winter (Lord and Lawson, 2008).

In this study, herbaceous flowering perennials were only included to survey the flowering period and plant height of herbaceous perennials available in Korea and to provide basic planting plans for flower borders. Out of 9 colors found in herbaceous flowering plants, 8 colors are found in flowers. There were many herbaceous perennials with white, yellow, purple and pink flowers and they were laid out along two flower borders created on both sides of a road. Only few perennials with red, orange, blue and green flowers were found in the gardens surveyed in this study. Those with flowers with red and orange, and blue and green were arranged opposite to each other respectively along each flower border. Based on the principle, 6 basic planting plans were suggested (Figs. 4-9).

When creating flower beds or borders, the characteristics of growth and development as well as visual elements need to be considered. Even if flower borders have a proper adaptability to soil and climate conditions (Brickell, 2002; Brickell, 2010; Brickell and Cathey, 2004), some plants die out due to a limited space, and some plants cannot grow with neighboring plants due to allelopathy depending on the depth of the soil layer that they occupy for various plants to take root (Lord and Lawson, 2008). However, it is difficult to consider all these elements in selecting plants in reality, and sufficient species of herbaceous flowering plants need to be prepared in order to consider as many elements as possible.

Figures 4-9 show basic planting plans for flower gardens $(10 \mathrm{~m} \times 3 \mathrm{~m})$ for different flower colors, and it was planned to plant one herbaceous perennial species (dividing them into three different plant heights: small, medium and large) in groups within a unit area of $1 \mathrm{~m} \times 1 \mathrm{~m}$ in a lattice pattern. In other countries, in order to maintain a natural atmosphere, plants are often planted in drifts as shown in Fig. 2 (Brickell and Cathey, 2004; Park and Yoo, 2004), but those planted in a lattice pattern can also naturally turn into the form of drifts as they grow. Above all, the lattice pattern was found to be suitable for the basic planting plans suggested in this study.

In terms of plant height, the role of small plants in the front row is the most important in flower beds or borders, and thus their leaves as well as flowers need to be beautiful and grow in a clean way. Low-lying carpet-like plants such as Lamb's ear are suitable for small plants, and round-shaped plants are mostly selected as a medium plant in order to hide the lower part of large plants behind them (Lord and Lawson, 2008). The height of plants used in flower borders is gradually increased in general, but a sense of change can be provided by making the height of herbaceous perennials irregular to some extent, which enables observers to see hidden parts from an inclined angle while walking from a long distance. Once the height and color of plants are determined, the shape and texture of herbaceous flowering plants need to be decided (Park and Yoo, 2011). Plants that have various shapes and textures among those of the same length, and visual effects can be improved by laying out contrast plants rather than similar plants when adjusting the shape and texture of plants (Young, 2009).

There were not enough objective data and species of plants that were found to flower for over one month among the surveyed plants to consider elements other than flower color, plant height and flowering period, and this survey was focused on flowering period and plant height. For this reason, herbaceous perennials of different flowering periods were 
not planned to be repeated by plant height for flower borders that flower throughout the year, but only one type was randomly arranged. Relatively many herbaceous flowering plants with white, yellow, purple and pink flowers were observed in this survey. Their plant height is not too small and their flowering period is also long. Their flowers can be seen easily and have a distinct texture, suitable for the climate conditions of Korea. Species that can be easily seen from different viewpoints were primarily arranged for flower borders in this study. Since there was almost no large plant other than yellow and purple flowering perennials, spaces were left blank, but they can be filled by placing other plants repeatedly, finding other large perennials that were not observed in the three surveyed places, or replacing them with the perennials that flower for less than one month but have a long plant height and a unique shape such as Helianthus, Ricinus communis, Alcea rosea and Celosia cristata.

Intervals for group planting need to be determined based on the size of mature plants, and a proper interval between two different species is $3 / 4$ of the sum of the intervals of each plant group (Lord and Lawson, 2008). The quantity of plants needs to be marked in planting plans based on these guidelines. However, planting intervals are provided in detail in illustrated plant books or in the catalogs of seed stores in other countries, but there is only information on intervals of some ground-cover plant seedlings available in Korea (Sohn, 2012). For this reason, the plant width of herbaceous perennials was not surveyed in this study, and thus the quantity of plants per unit area $\left(1 \mathrm{~m}^{2}\right)$ was not marked here. Flower borders usually use many plants compared to the quantity of ground-cover plant seedlings marked per unit area $\left(1 \mathrm{~m}^{2}\right)$ in Korea, and 1-5 pieces (at most 10 pieces) of medium and large plants are usually planted in the unit area in odd numbers (Brickell, 2007; Oudolf and Gerritsen, 2003; Oudolf and Kingsbury, 2017). They can be planted closer in the first year, but some might need to be thinned out in the next year when the area of the herbaceous perennials becomes wider (Lord and Lawson, 2008). The reason why one species was planned to be planted in a unit area $\left(1 \mathrm{~m}^{2}\right)$ for the $3 \mathrm{~m}$-width flower border in this study is that the unit area seems to be suitable for the suggested plans compared to other actual flower borders in photos (Fig. 2), and that the unit area, if necessary, can be adjusted depending on the purposes of gardens. For this reason, this study suggested basic and general standard forms.

Basic planting designs were suggested based on the quantity of flowers observed in the three places surveyed in this study as following: white, yellow, purple, pink, red/orange, and blue/green.

\section{White}

Hantaek Botanical Garden and Mulhyanggi Arboretum selected in this study have many herbaceous flowering plants, and, in particular, 85 species were found to have white flowers that flowered for over one month, but the number of herbaceous perennials of a plant height of over $120 \mathrm{~cm}$ was only 10 (11.8\%) (Table 2). There were more medium and small flowers than those marked in the planned flower border shown in Fig. 4, and in particular there were relatively many small flowers (46 species, 54.1\%) (Table 2). However, since flowers smaller than $60 \mathrm{~cm}$ need to be at least $20 \mathrm{~cm}$ in order to maintain balance for the $3 \mathrm{~m}$-width flower border here, very small plants were excluded from this plan. Hosta and Astilbe genera have so many species and varieties and are widely used in Korea. Plantain lilies that is widely known was separately arranged, and the rest were marked with the overall flowering period of species or varieties by color.

Traditional flower borders that are created on both sides of a road do not need to be identical, but to give a sense of harmony and balance, the same species of plants are planted repeatedly on both sides (Brickell, 2007). In this study, the same herbaceous perennials were not arranged for each flower border created on both sides of a road in order to suggest various herbaceous perennials of different flowering periods and plant heights surveyed in this study. Digitalis is categorized as a biennial or perennial plant, but they can be recognized as a perennial plant considering the growth and development of those found in Mulhyanggi Arboretum, and thus was included in the suggested plan. Of 9 flower colors of 


\begin{tabular}{|c|c|c|c|c|c|c|c|c|c|c|}
\hline L & \begin{tabular}{|c|} 
Digitalis \\
purpurea \\
'Camelot Cream' \\
카멜로ㅅㅡㅡ리리 \\
디기탈리스 \\
$(5.25-6.15)$ \\
\end{tabular} & & $\begin{array}{c}\text { Angelica } \\
\text { dahurica } \\
\text { 구릿대 } \\
(8.5-8.25)\end{array}$ & & $\begin{array}{c}\text { Angelica } \\
\text { polymorpha } \\
\text { 궁궁이 } \\
(8.15-10.5)\end{array}$ & & $\begin{array}{c}\text { Pycnanthemum } \\
\text { tenuifolium } \\
\text { 버지니아민트 } \\
\text { (7.15-9.15) }\end{array}$ & & $\begin{array}{c}\text { Heracleum } \\
\text { moellendorffii } \\
\text { 어수리 } \\
(6.15-7.15)\end{array}$ & \\
\hline $\mathrm{M}$ & $\begin{array}{l}\text { Astilbe spp. } \\
\text { 아스틸베 } \\
(6.5-6.25)\end{array}$ & $\begin{array}{c}\text { Actaea } \\
\text { matsumurae } \\
\text { 'White Pearl' } \\
\text { 화이트펄 승마 } \\
(9.25-10.25)\end{array}$ & $\begin{array}{c}\text { Aster scaber } \\
\quad \text { 참취 } \\
(8.5-9.25)\end{array}$ & $\begin{array}{l}\text { Liatris spicata } \\
\text { 'Alba' } \\
\text { 흰리아트리스 } \\
\text { (7.15-8.5) }\end{array}$ & $\begin{array}{c}\text { Dystaenia } \\
\text { takesimana } \\
\text { 섬바디 } \\
(6.25-7.25)\end{array}$ & $\begin{array}{c}\text { Echinacea } \\
\text { purpurea } \\
\text { 'White Swan' } \\
\text { 화이트 스완 } \\
\text { 에키나세아 } \\
(6.25-8.5) \\
\end{array}$ & \begin{tabular}{|c|} 
Aster \\
ageratoides \\
subsp. \\
amplexifolius \\
흰까실쑥부쟁이 \\
$(9.5-11.5)$ \\
\end{tabular} & $\begin{array}{c}\text { Lilium } \\
\text { 'Casa Blanca' } \\
\text { 카사블랑카 } \\
\text { 나리 } \\
(7.5-7.25)\end{array}$ & \begin{tabular}{|c} 
Peucedanum \\
japonicum \\
갯기름나물 \\
$(6.5-7.25)$
\end{tabular} & $\begin{array}{l}\text { Achillea } \\
\text { millefolium } \\
\text { 'Colorado' } \\
\text { 서양톱풀 } \\
(6.5-7.15)\end{array}$ \\
\hline S & $\begin{array}{c}\text { Astilbe spp. } \\
\text { 아스틸베 } \\
(5.25-6.15)\end{array}$ & $\begin{array}{c}\text { Primula } \\
\text { denticulata } \\
\text { 'Alba' } \\
\text { 덴티큘라타 } \\
\text { 알바 프리뮬라 } \\
\text { (4.5-4.25) }\end{array}$ & $\begin{array}{c}\text { Phlox stolonifera } \\
\text { 'Bruce's White' } \\
\text { 부르스 화이트 } \\
\text { 플록스 } \\
(5.5-5.25)\end{array}$ & $\begin{array}{c}\text { Allium } \\
\text { tuberosum } \\
\text { 부추 } \\
(8.15-9.15)\end{array}$ & $\begin{array}{c}\text { Anemone } \\
\text { canadensis } \\
\text { 아네모네 } \\
(5.25-6.15)\end{array}$ & $\begin{array}{c}\text { Mukdenia } \\
\text { rossii } \\
\text { 돌단풍 } \\
(3.25-5.15)\end{array}$ & $\begin{array}{c}\text { Saponaria } \\
\text { officinalis } \\
\text { 비누풀 } \\
(6.15-7.5)\end{array}$ & $\begin{array}{l}\text { Tulipa spp. } \\
\quad \text { 튤립 } \\
(4.15-5.15)\end{array}$ & $\begin{array}{c}\text { Aquilegia } \\
\text { flabellata } \\
\text { var. pumila } \\
\text { 매발톱꽃 } \\
(5.5-5.25) \\
\end{array}$ & $\begin{array}{c}\text { Anemone } \\
\text { koraiensis } \\
\text { 홀아비바람꽃 } \\
(4.15-5.25)\end{array}$ \\
\hline
\end{tabular}

\begin{tabular}{|c|c|c|c|c|c|c|c|c|c|c|}
\hline \multicolumn{11}{|c|}{ Path } \\
\hline S & $\begin{array}{l}\text { Dracocephalum } \\
\text { argunense } \\
\text { 'Fuji White' } \\
\text { 흰용머리 } \\
(6.5-6.25)\end{array}$ & $\begin{array}{c}\text { Hosta } \\
\text { plantaginea } \\
\text { 옥잠화 } \\
(8.5-9.5)\end{array}$ & $\begin{array}{c}\text { Narcissus } \\
\text { 'Las Vegas' } \\
\text { 수선화 } \\
\text { 라스베가스 } \\
\text { (4.5-5.5) }\end{array}$ & $\begin{array}{c}\text { Chrysanthe- } \\
\text { mum } \\
\text { zawadskii var. } \\
\text { latilobum } \\
\text { 구절초 } \\
(9.25-11.15) \\
\end{array}$ & $\begin{array}{c}\text { Angelica } \\
\text { tenuissima } \\
\text { 고본 } \\
(8.25-10.5)\end{array}$ & $\begin{array}{c}\text { Helleborus } \\
\text { orientalis } \\
\text { 헬레보러스 } \\
(4.5-5.25)\end{array}$ & \begin{tabular}{|c} 
Chrysanthe- \\
mum \\
morifolium $\mathrm{ssp}$. \\
국화 \\
$(9.15-11.25)$
\end{tabular} & $\begin{array}{c}\text { Campanula } \\
\text { punctata } \\
\text { 초롱꽃 } \\
(6.5-7.5)\end{array}$ & \begin{tabular}{|c|} 
Astrantia major \\
'Alba' \\
아스트란티아 \\
알바 \\
$(6.5-7.25)$
\end{tabular} & $\begin{array}{l}\text { Cimicifuga } \\
\text { japonica } \\
\text { 왜승마 } \\
(9.15-10.5)\end{array}$ \\
\hline M & $\begin{array}{c}\text { Penstemon } \\
\text { digitalis } \\
\text { 'Husker Red' } \\
\text { 허스커레드 } \\
\text { 펜스테몬 } \\
(5.25-6.15) \\
\end{array}$ & $\begin{array}{l}\text { Angelica } \\
\text { acutiloba } \\
\text { 일당귀 } \\
(6.15-7.5)\end{array}$ & $\begin{array}{l}\text { Physostegia } \\
\text { virginiana } \\
\text { 'Alba' } \\
\text { 흰꽃범의꼬리 } \\
(8.15-9.5)\end{array}$ & $\begin{array}{c}\text { Chrysanthe- } \\
\text { mum } \\
\text { burbankii } \\
\text { 샤스타데이지 } \\
(5.15-6.25)\end{array}$ & $\begin{array}{l}\text { Lysimachia } \\
\text { clethroides } \\
\text { 큰까치수염 } \\
(6.15-7.5)\end{array}$ & $\begin{array}{c}\text { Verarum } \\
\text { grandiflora } \\
\text { 박새 } \\
(5.25-6.15)\end{array}$ & $\begin{array}{c}\text { Gaura } \\
\text { lindheimeri } \\
\text { 흰가우라 } \\
(6.25-10.5)\end{array}$ & $\begin{array}{c}\text { Aruncus } \\
\text { dioicus } \\
\text { var. } \\
\text { kamtschaticus } \\
\text { 눈개승마 } \\
\text { (5.25-6.15) } \\
\end{array}$ & $\begin{array}{c}\text { Phlox } \\
\text { paniculata } \\
\text { 'David' } \\
\text { 플록스 백설 } \\
(7.15-9.5)\end{array}$ & $\begin{array}{c}\text { Cimicifuga } \\
\text { racemosa var. } \\
\text { Cordifolia } \\
\text { 코디폴리아 } \\
\text { 승마 } \\
(8.5-9.5) \\
\end{array}$ \\
\hline $\mathrm{L}$ & $\begin{array}{c}\text { Nepeta cataria } \\
\text { 개박하 } \\
(7.5-8.5)\end{array}$ & & $\begin{array}{l}\text { Fallopia } \\
\text { japonica } \\
\text { 호장근 } \\
(9.5-10.5)\end{array}$ & & $\begin{array}{c}\text { Eupatorium } \\
\text { japonicum } \\
\text { 등골나물 } \\
(7.15-8.15)\end{array}$ & & $\begin{array}{l}\text { Eupatorium } \\
\text { maculatum } \\
\text { 'Snowball' } \\
\text { 스노우볼 } \\
\text { 등골나물 } \\
(7.25-8.15)\end{array}$ & & & \\
\hline
\end{tabular}

Figure 4. Flower border layout $(10 \mathrm{~m} \times 3 \mathrm{~m})$ with white flowers which have more than one month of flowering period. Each flower border is placed on either side of central path. Plants of same species are randomly placed in each 1 $\mathrm{m} \times 1 \mathrm{~m}$ unit area. Each border was designed with large plants $(\mathrm{L}:$ over $120 \mathrm{~cm})$ in the back, medium plants (M: $60-120 \mathrm{~cm}$ ) in the middle, and small plant $(\mathrm{S}:$ below $60 \mathrm{~cm}$ ) toward the front of flower border. Only flower color, plant height and flowering period of perennials surveyed in this study were considered for this layout. Dates in parentheses represent flowering period of each species.

herbaceous flowering plants, white flowers are so widely used that there are even white gardens solely composed of white flowers (Park, 2010a). Large plants that are not widely used in general gardens such as Angelica dahurica, Angelica polymorpha, Heracleum moellendorffii, and Fallopia japonica were included, and it is still necessary to develop and introduce various herbaceous perennials with white flowers that have ornamental values.

\section{Yellow}

There were 79 herbaceous perennials with yellow flowers in the three places, and, unlike those with white flowers, there were many large perennials of a plant height of over $120 \mathrm{~cm}$ (18 species, 22.8\%). However, there were only few medium perennials that flowered for over one month (14 species, 17.7\%), not enough to fill all the 20 unit areas (Table 2, Fig. 5). Hantaek Botanical Garden has many large Rudbeckia varieties, and two large Silphium varieties that are hardly seen in other places were observed in the garden. It has relatively many large plants such as Patrinia scabiosaefolia, Verbascum nigrum, and Helianthus salicifolius 'First Light', and thus flower gardens with the theme of yellow seemed to be relatively luxuriant (Oudolf and Kingsbury, 2005). Verbascum nigrum or Silphium varieties have solid stems and thus are not easily affected by the rainy season or typhoons, but Helianthus salicifolius 'First Light' that flowers in the fall often leans sideways during its flowering period, which may not be suitable for flower borders that do not pursue a natural atmosphere. In particular, one of native plants, Patrinia scabiosifolia, flowers for almost 3 months, and considering its 


\begin{tabular}{|c|c|c|c|c|c|c|c|c|c|c|}
\hline L & $\begin{array}{c}\text { Inula helenium } \\
\text { 목향 } \\
(6.15-7.5)\end{array}$ & $\begin{array}{c}\text { Rudbeckia } \\
\text { laciniata } \\
\text { 'Hortensia' } \\
\text { 홀텐시아 } \\
\text { 루드베키아 } \\
\text { (7.15-8.15) }\end{array}$ & $\begin{array}{l}\text { Verbascum } \\
\text { nigrum } \\
\text { 버바스쿰 } \\
(5.25-7.5)\end{array}$ & $\begin{array}{c}\text { Solidago } \\
\text { virgaurea } \text { ssp. } \\
\text { asiatica } \text { 미역취 } \\
(7.5-8.5)\end{array}$ & \begin{tabular}{|} 
Silphium \\
radula 라듈라 \\
실피움 \\
$(7.15-8.25)$
\end{tabular} & \begin{tabular}{|} 
Cota tinctoria \\
다이어스 \\
캐모마일 \\
$(6.5-7.15)$
\end{tabular} & $\begin{array}{c}\text { Silphium } \\
\text { perfoliatum } \\
\text { 퍼폴리아텀 } \\
\text { 실피움 } \\
(7.15-8.25)\end{array}$ & \begin{tabular}{|} 
Thalictrum \\
speciossimum \\
노랑뀡의다리 \\
$(6.15-.7 .25)$
\end{tabular} & $\begin{array}{l}\text { Agrimonia } \\
\text { pilosa } \\
\text { 짚신나물 } \\
(7.15-9.5)\end{array}$ & $\begin{array}{c}\text { Rudbeckia } \\
\text { laciniata } \\
\text { 'Herbstsonne' } \\
\text { 허브스트소네 } \\
\text { 루드베키아 } \\
\text { (7.5-8.5) } \\
\end{array}$ \\
\hline $\mathrm{M}$ & & $\begin{array}{c}\text { Achillea } \\
\text { millefolium } \\
\text { 'Coronation } \\
\text { Gold' } \\
\text { 톱풀 골드 } \\
(6.5-7.15) \\
\end{array}$ & $\begin{array}{l}\text { Solidaster } \\
\text { luteus } \\
\text { 솔리대스터 } \\
(9.5-10.5)\end{array}$ & $\begin{array}{c}\text { Kirengeshoma } \\
\text { koreana } \\
\text { 나도승마 } \\
(6.25-7.15)\end{array}$ & $\begin{array}{c}\text { Iris } \\
\text { pseudacorus } \\
\text { 노랑꽃창포 } \\
(5.15-6.5)\end{array}$ & & $\begin{array}{c}\text { Hypericum } \\
\text { perforatum } \\
\text { 세인트존스워트 } \\
(6.15-7.15)\end{array}$ & $\begin{array}{c}\text { Dendranthema } \\
\text { boreale } \\
\text { 산국 } \\
(10.5-11.5)\end{array}$ & & $\begin{array}{c}\text { Lysimachia } \\
\text { ciliata } \\
\text { 'Firecracker' } \\
\text { 자주잎 좁쌀풀 } \\
(6.25-7.15)\end{array}$ \\
\hline S & $\begin{array}{c}\text { Narcissus } \\
\text { 'Dutch Master' } \\
\text { 더취 마스터 } \\
\text { 수선화 } \\
(4.5-5.5)\end{array}$ & \begin{tabular}{|c|} 
Chrysanthe- \\
mum \\
morifolium ssp. \\
국화 \\
$(9.25-12.5)$
\end{tabular} & $\begin{array}{c}\text { Caltha } \\
\text { palustris var. } \\
\text { palustris } \\
\text { 동의나물 } \\
(3.25-5.15)\end{array}$ & $\begin{array}{c}\text { Hemerocallis } \\
\text { minor } \\
\text { 애기원추리 } \\
(5.25-6.15)\end{array}$ & $\begin{array}{c}\text { Dahlia 'Happy } \\
\text { Single Party' } \\
\text { 해피 싱글 파티 } \\
\text { 달리아 } \\
(7.5-10.25)\end{array}$ & $\begin{array}{l}\text { Coreopsis } \\
\text { auriculata } \\
\text { 'Elfin Gold' } \\
\text { 코레옵시스 } \\
\text { 엘핀골드 } \\
(5.25-8.25) \\
\end{array}$ & $\begin{array}{l}\text { Hylomecon } \\
\text { vernalis } \\
\text { 피나물 } \\
(4.15-5.25)\end{array}$ & $\begin{array}{l}\text { Ligularia } \\
\text { fischeri } \\
\text { 곰취 } \\
(8.5-10.5)\end{array}$ & $\begin{array}{c}\text { Dendranthema } \\
\text { indicum } \\
\text { 감국 } \\
(10.25-12.15)\end{array}$ & $\begin{array}{c}\text { Galium verum } \\
\text { var. asiaticum } \\
\text { 솔나물 } \\
(6.15-7.5)\end{array}$ \\
\hline \multicolumn{11}{|c|}{ Path } \\
\hline$S$ & $\begin{array}{c}\text { Coreanomecon } \\
\text { hylomeconoides } \\
\text { 매미꽃 } \\
(4.15-7.5)\end{array}$ & $\begin{array}{l}\text { Rudbeckia } \\
\text { fulgida } \\
\text { 풀기다 } \\
\text { 루드베키아 } \\
\text { (7.15-9.25) }\end{array}$ & $\begin{array}{c}\text { Ajania pacifica } \\
\text { 개ㅅㅜㅜㄱ } \\
(10.25-11.25)\end{array}$ & $\begin{array}{c}\text { Coreopsis } \\
\text { verticillata } \\
\text { 'Zagreb' } \\
\text { 솔잎금계국, } \\
\text { '자그레브' } \\
(6.15-8.25) \\
\end{array}$ & $\begin{array}{c}\text { Digitalis } \\
\text { grandiflora } \\
\text { 디기탈리스 } \\
(6.5-6.25)\end{array}$ & \begin{tabular}{|c|} 
Gaillardia \\
grandiflora \\
'Mesa Yellow' \\
메사옐로우 \\
큰꽃천인국 \\
$(6.5-11.15)$ \\
\end{tabular} & $\begin{array}{c}\text { Corydalis } \\
\text { speciosa } \\
\text { 산괴불주머니 } \\
(3.25-6.5)\end{array}$ & $\begin{array}{c}\text { Primula veris } \\
\text { 베리스 } \\
\text { 프리뮬라 } \\
(4.15-5.15)\end{array}$ & $\begin{array}{l}\text { Echinacea } \\
\text { 'Sunrise' } \\
\text { 에키나세아 } \\
\text { 선라이즈 } \\
(6.15-8.5)\end{array}$ & $\begin{array}{l}\text { Adonis } \\
\text { amurensis } \\
\text { 복수초 } \\
(3.5-5.5)\end{array}$ \\
\hline $\mathrm{M}$ & $\begin{array}{c}\text { Lilium } \\
\text { 'Yelloween' } \\
\text { 옐로윈 나리 } \\
(6.25-7.15)\end{array}$ & & $\begin{array}{c}\text { Helenium } \\
\text { autumnale } \\
\text { 'Helena Gold' } \\
\text { 헬레니움 황금 } \\
(8.15-9.5)\end{array}$ & & $\begin{array}{c}\text { Coreopsis } \\
\text { lanceolata } \\
\text { 큰금계국 } \\
(6.5-6.25)\end{array}$ & \begin{tabular}{|c|}
$\begin{array}{c}\text { Ligularia } \\
\text { przewalskii } \\
\text { 프셰발스키곰취 } \\
(6.15-7.5)\end{array}$ \\
\end{tabular} & $\begin{array}{l}\text { Bupleurum } \\
\text { latissimum } \\
\text { 섬시호 } \\
(5.25-6.15)\end{array}$ & $\begin{array}{c}\text { Lysimachia } \\
\text { coreana } \\
\text { 참좁쌀풀 } \\
(6.15-7.5)\end{array}$ & & $\begin{array}{l}\text { Lysimachia } \\
\text { vulgaris var. } \\
\text { davurica } \\
\text { 좁쌀풀 } \\
(6.15-7.5)\end{array}$ \\
\hline $\mathrm{L}$ & $\begin{array}{c}\text { Rudbeckia } \\
\text { troloba } \\
\quad \text { 애기 } \\
\text { 루드베키아 } \\
\text { (7.25-9.15) }\end{array}$ & $\begin{array}{c}\text { Solidago } \\
\text { serotina } \\
\text { 미국미역취 } \\
(10.5-11.5)\end{array}$ & $\begin{array}{c}\text { Rudbeckia } \\
\text { subtomentosa } \\
\text { 서브토ㅁㅔㅔ토사 } \\
\text { 루드베키아 } \\
(8.5-9.15)\end{array}$ & $\begin{array}{c}\text { Hemerocallis } \\
\text { thunbergii } \\
\text { 노랑원추리 } \\
(7.15-8.5)\end{array}$ & \begin{tabular}{l|} 
Helianthus \\
salicifolius \\
'First Light' \\
펄스트라이트 \\
해바라기 \\
$(9.25-10.25)$ \\
\end{tabular} & $\begin{array}{l}\text { Tanacetum } \\
\text { vulgare } \\
\text { 탠지 } \\
(7.25-8.25)\end{array}$ & & $\begin{array}{c}\text { Patrinia } \\
\text { scabiosifolia } \\
\text { 마타리 } \\
(7.15-10.5)\end{array}$ & $\begin{array}{c}\text { Rudbeckia } \\
\text { triloba'Prairie } \\
\text { Glow' } \\
\text { 프레리글로우 } \\
\text { 애기루드베키아 } \\
\text { (7.5-8.15) } \\
\end{array}$ & \\
\hline
\end{tabular}

Figure 5. Flower border layout $(10 \mathrm{~m} \times 3 \mathrm{~m})$ with yellow flowers which have more than one month of flowering period. Each flower border is placed on either side of central path. Plants of same species are randomly placed in each $1 \mathrm{~m}$ $\times 1 \mathrm{~m}$ unit area. Each border was designed with large plants $(\mathrm{L}:$ over $120 \mathrm{~cm})$ in the back, medium plants (M: $60-120 \mathrm{~cm}$ ) in the middle, and small plant (S: below $60 \mathrm{~cm}$ ) toward the front of flower border. Only flower color, plant height and flowering period of perennials surveyed in this study were considered for this layout. Dates in parentheses represent flowering period of each species.

strong growth behaviors and the shape and texture of its stems and flowers, it can be widely used to create more dynamic flower borders.

\section{Purple}

There were many herbaceous perennials with purple flowers (73 species), but small herbaceous perennials accounted for a large share (47 species, 64.4\%). There were only few large and even medium perennials (13 species, 17.8\%) for flower borders, not enough to fill all the 20 unit areas (Table 2, Fig. 6). There were only 13 species of large perennials (17.8\%), the second highest, following yellow, out of 8 flower colors. Herbaceous perennials that are not easily observed in other places such as Thalictrum rochebrunianum var. grandisepalum, Aster tataricus, Cirsium japonicum var. maackii and Veronicastrum sibiricum, and Vernonia, Nepeta and Campanula varieties were included in the flower border suggested below, but it is still necessary to develop other large and medium herbaceous perennials. Flower borders composed of purple flowers are not commonly created in the United Kingdom, but the purple flower border created in Sissinghurst Castle Garden proves its real worth in gloomy and dismal days, or early in the morning, or at dawn, or in cloudy days (Park, 2010b). As these show, herbaceous perennials with purple flowers seem to play an important role in gardens. 


\begin{tabular}{|c|c|c|c|c|c|c|c|c|c|c|}
\hline & & \begin{tabular}{|c} 
Cirsium \\
japonicum var. \\
maackii \\
엉겅퀴 \\
$(5.25-6.25)$
\end{tabular} & $\begin{array}{c}\text { Vernonia } \\
\text { noveboracensis } \\
\text { 베르노니아 } \\
\text { 노베보라켄시스 } \\
(7.15-9.25)\end{array}$ & $\begin{array}{c}\text { Nepeta } \\
\text { grandiflora } \\
\text { 'Wild Cat' } \\
\text { 와일드캣 } \\
\text { 네페타 } \\
(6.15-7.5)\end{array}$ & $\begin{array}{c}\text { Aster tataricus } \\
\text { var. floribundus } \\
\text { 꽃개미취 } \\
(9.25-11.5)\end{array}$ & & $\begin{array}{c}\text { Angelica gigas } \\
\text { 참당귀 } \\
(8.15-9.15)\end{array}$ & $\begin{array}{l}\text { Campanula } \\
\text { pyramidalis } \\
\text { 피라미달리스 } \\
\text { 캄파눌라 } \\
(6.15-7.5)\end{array}$ & $\begin{array}{l}\text { Veronicastrum } \\
\text { sibiricum } \\
\text { 냉초 } \\
(7.5-7.25)\end{array}$ & \\
\hline & $\begin{array}{c}\text { Scabiosa } \\
\text { atropurpurea } \\
\text { 아트로퍼퍼레 } \\
\text { 아 스카비오사 } \\
(5.25-6.25)\end{array}$ & $\begin{array}{l}\text { Aster spp. } \\
\text { 아스터 } \\
(8.5-8.25)\end{array}$ & $\begin{array}{l}\text { Iris laevigata } \\
\quad \text { 제비붓꽃 } \\
(5.5-5.25)\end{array}$ & & \begin{tabular}{|c|} 
Iris ensata \\
var. spontanea \\
꽃창포 \\
$(5.25-6.25)$
\end{tabular} & & $\begin{array}{l}\text { Aquilegia } \\
\text { canadensis } \\
\text { 카나덴시스 } \\
\text { 매발토ㅂㅗㅗㅊ } \\
(5.5-6.5)\end{array}$ & $\begin{array}{l}\text { Sanguisorba } \\
\text { officinalis } \\
\text { 오이풀 } \\
(8.15-9.5)\end{array}$ & & $\begin{array}{c}\text { Aster yomena } \\
\text { 쑥부쟁이 } \\
(9.5-10.15)\end{array}$ \\
\hline & $\begin{array}{l}\text { Iris setosa } \\
\text { 부채붓꽃 } \\
(5.15-6.5)\end{array}$ & \begin{tabular}{|c} 
Stokesia laevis \\
스토케시아 \\
(7.25-8.25)
\end{tabular} & $\begin{array}{c}\text { Salvia } \\
\text { nemerosa } \\
\text { 'Caradonna' } \\
\text { 카라돈나 살비아 } \\
(5.15-6.15)\end{array}$ & $\begin{array}{c}\text { Aster } \\
\text { koraiensis } \\
\text { 벌개미취 } \\
(7.15-9.25)\end{array}$ & $\begin{array}{c}\text { Pulmonaria } \\
\text { 'Blue Ensign' } \\
\text { 블루 엔사인 } \\
\text { 풀모나리아 } \\
\text { (4.5-5.5) }\end{array}$ & $\begin{array}{c}\text { Aster } \\
\text { ageratoides } \\
\text { 'Ezo Murasaki' } \\
\text { 청화 쑥부쟁이 } \\
(9.25-11.15)\end{array}$ & $\begin{array}{c}\text { Scabiosa } \\
\text { tschiliensis } \\
\text { 솔체꽃 } \\
(8.15-9.25)\end{array}$ & $\begin{array}{c}\text { Thalictrum } \\
\text { uchiyamae } \\
\text { 자주뀡의다리 } \\
\text { (6.5-7.15) }\end{array}$ & $\begin{array}{l}\text { Campanula } \\
\text { takesimana } \\
\text { 섬초롱꽃 } \\
(6.15-7.5)\end{array}$ & $\begin{array}{l}\text { Aquilegia spp. } \\
\text { 매발톱꽃 } \\
(4.25-6.5)\end{array}$ \\
\hline
\end{tabular}

\begin{tabular}{|c|c|c|c|c|c|c|c|c|c|c|}
\hline \multicolumn{11}{|c|}{ Path } \\
\hline $\mathrm{S}$ & \begin{tabular}{|c|} 
Thalictrum \\
actaefolium \\
var. brevistylum \\
은뀡의다리 \\
$(7.25-9.5)$
\end{tabular} & \begin{tabular}{|c} 
Chrysanthe- \\
mum \\
morifolium ssp. \\
국화 \\
$(9.15-10.5)$
\end{tabular} & $\begin{array}{c}\text { Aster } \\
\text { ageratoides } \\
\text { 까실쑥부쟁이 } \\
(9.15-11.5)\end{array}$ & $\begin{array}{l}\text { Helleborus } \\
\quad \text { niger } \\
\text { 헬레보러스 } \\
(4.5-5.25)\end{array}$ & $\begin{array}{l}\text { Aster spp. } \\
\text { 아스터 } \\
(7.15-8.5)\end{array}$ & $\begin{array}{c}\text { Aster } \\
\text { spathulifolius } \\
\text { var. oharai } \\
\text { 왕해국 } \\
(9.25-10.25)\end{array}$ & $\begin{array}{c}\text { Corydalis } \\
\text { incisa } \\
\text { 자주괴불주머니 } \\
(4.5-5.15)\end{array}$ & $\begin{array}{c}\text { Pulsatilla } \\
\text { koreana } \\
\text { 할미꽃 } \\
(4.5-5.5)\end{array}$ & $\begin{array}{c}\text { Salvia } \\
\text { verticillata } \\
\text { 'Purple Rain' } \\
\text { 퍼플레인 } \\
\text { 살비아 } \\
(6.15-7.5) \\
\end{array}$ & $\begin{array}{c}\text { Hosta yingeri } \\
\text { 홍도비비추 } \\
(8.5-8.25)\end{array}$ \\
\hline $\mathrm{M}$ & & $\begin{array}{c}\text { Liatris spicata } \\
\text { 리아트리스 } \\
(6.25-8.5)\end{array}$ & $\begin{array}{c}\text { Lobelia } \\
\text { sessilifolia } \\
\text { 숫잔대 } \\
(7.25-9.25)\end{array}$ & $\begin{array}{c}\text { Allium } \\
\text { thunbergii } \\
\text { 산부추 } \\
(9.25-10.25)\end{array}$ & & $\begin{array}{c}\text { Serratula } \\
\text { coronata var. } \\
\text { insularis } \mathrm{f} . \\
\text { insularis } \\
\text { 산비장이 } \\
(7.25-9.15) \\
\end{array}$ & & $\begin{array}{l}\text { Iris ensata ssp. } \\
\text { 꽃창포 } \\
(5.15-6.25)\end{array}$ & $\begin{array}{c}\text { Veratrum } \\
\text { nigrum var. } \\
\text { ussuriense } \\
\text { 참여로 } \\
(8.15-9.5)\end{array}$ & \\
\hline $\mathrm{L}$ & \begin{tabular}{|c|} 
Digitalis \\
purpurea \\
'Camelot Rose' \\
카멜롯 로즈 \\
디기탈리스 \\
$(5.25-6.15)$ \\
\end{tabular} & & $\begin{array}{l}\text { Thalictrum } \\
\text { rochebrunia- } \\
\text { num var. } \\
\text { grandisepalum } \\
\text { 금뀡의다리 } \\
\text { (7.5-8.25) }\end{array}$ & $\begin{array}{c}\text { Agastache } \\
\text { rugosa 'Golden } \\
\text { Jubilee' } \\
\text { 황금배초향 } \\
(6.25-8.5)\end{array}$ & $\begin{array}{c}\text { Aster tataricus } \\
\text { 개미취 } \\
(7.15-9.15)\end{array}$ & $\begin{array}{l}\text { Verbena } \\
\text { officinalis } \\
\text { 마편초 } \\
(6.15-7.5)\end{array}$ & $\begin{array}{c}\text { Aconitum } \\
\text { jaluense } \\
\text { 투구꽃 } \\
(9.25-10.25)\end{array}$ & & $\begin{array}{l}\text { Agastache } \\
\text { rugosa } \\
\text { 배초향 } \\
(7.5-10.15)\end{array}$ & \\
\hline
\end{tabular}

Figure 6. Flower border layout $(10 \mathrm{~m} \times 3 \mathrm{~m})$ with purple flowers which have more than one month of flowering period. Each flower border is placed on either side of central path. Plants of same species are randomly placed in each $1 \mathrm{~m}$ $\times 1 \mathrm{~m}$ unit area. Each border was designed with large plants $(\mathrm{L}:$ over $120 \mathrm{~cm})$ in the back, medium plants (M: $60-120 \mathrm{~cm}$ ) in the middle, and small plant (S: below $60 \mathrm{~cm}$ ) toward the front of flower border. Only flower color, plant height and flowering period of perennials surveyed in this study were considered for this layout. Dates in parentheses represent flowering period of each species.

\section{Pink}

There were many herbaceous perennials with pink flowers (72 species), but there were only 8 large species of herbaceous perennials of a plant height of over $120 \mathrm{~cm}$ (11.1\%), not enough to fill all the 20 unit areas (Table 2, Fig. 7). Of the surveyed large herbaceous perennials, Eupatorium maculatum 'Gateway', unlike Eupatorium tripartitum that is widely used in Korea, was found to flower for nearly 2 months and to feature long plant heights, thick stems and large flowers, and thus can be very useful to create gardens. Lythrum anceps shows a big difference in plant height between planted areas, and there were many colonies that grew very large, over $120 \mathrm{~cm}$, in the surveyed gardens. Most grasses that do not have distinct flowers were excluded from this study, but Muhlenbergia capillaris was included as their flower color is very distinct and recently it has been planted in many places in Korea.

\section{Red and orange}

The number of herbaceous perennials with red and orange flowers was 18 species respectively, which was much lower than that of perennials with white, yellow, purple and pink flowers. These results were similar to the results of a study on the list of herbaceous flowering plants of farms and botanical gardens in Korea (Sohn, 2013). Either red or orange flowers were laid out on only one flower border, but it was still not enough to fill the planned unit areas (Table 2, Fig. 8). In particular, only one and two species of a plant height of over $120 \mathrm{~cm}$ had red and orange flowers respectively. This can be 


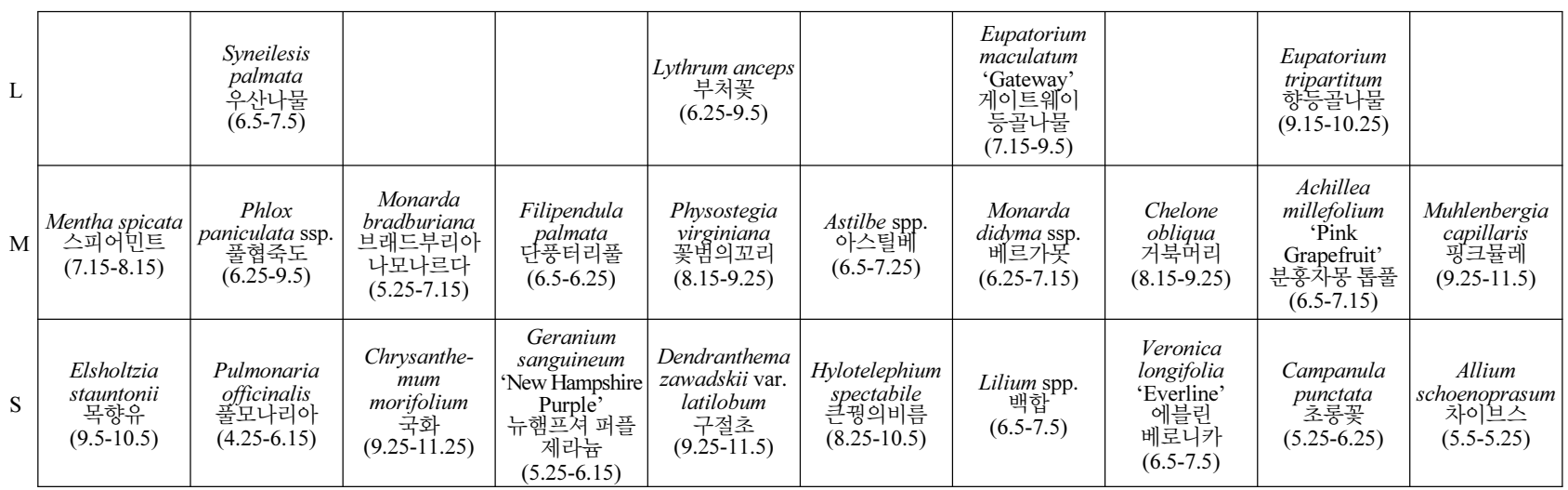

\begin{tabular}{|c|c|c|c|c|c|c|c|c|c|c|}
\hline & \multicolumn{10}{|c|}{ Path } \\
\hline $\mathrm{S}$ & $\begin{array}{c}\text { Primula } \\
\text { sieboldii } \\
\text { 앵초 } \\
(4.25-5.15)\end{array}$ & $\begin{array}{c}\text { Primula } \\
\text { denticulata } \\
\text { 덴티큘라타 } \\
\text { 프리뮬라 } \\
(4.5-4.25)\end{array}$ & $\begin{array}{c}\text { Dianthus } \\
\text { gratianopolita- } \\
\text { nus 'Firewitch' } \\
\text { 파이어 위치 } \\
\text { 다이안서스 } \\
(5.15-6.15)\end{array}$ & $\begin{array}{c}\text { Oenothera } \\
\text { speciosa } \\
\text { 분홍달맞이꽃 } \\
(5.15-6.25)\end{array}$ & $\begin{array}{c}\text { Primula } \\
\text { japonica'Apple } \\
\text { Blossom' } \\
\text { 애플 블로섬 } \\
\text { 일본앵초 } \\
(5.5-6.5)\end{array}$ & $\begin{array}{l}\text { Helleborus } \\
\text { niger } \\
\text { 헬레보러스 } \\
(4.5-5.25)\end{array}$ & $\begin{array}{c}\text { Allium } \\
\text { senescens } \\
\text { 두메부추 } \\
(8.15-9.25)\end{array}$ & $\begin{array}{c}\text { Aster } \\
\text { meyendorfii } \\
\text { 개쑥부쟁이 } \\
(9.15-10.5)\end{array}$ & $\begin{array}{c}\text { Dahlia 'Gallery } \\
\text { Art Nouveau' } \\
\text { 갤러리 아트 } \\
\text { 누보 달리아 } \\
\text { (6.25-10.25) }\end{array}$ & $\begin{array}{c}\text { Dicentra } \\
\text { spectabilis } \\
\text { 금낭화 } \\
(4.15-5.15)\end{array}$ \\
\hline M & $\begin{array}{c}\text { Echinacea } \\
\text { purpurea } \\
\text { 에키나시아 } \\
(6.15-8.15)\end{array}$ & $\begin{array}{l}\text { Origanum } \\
\text { vulgare } \\
\text { 오레가노 } \\
(6.15-7.25)\end{array}$ & $\begin{array}{l}\text { Valeriana } \\
\text { fauriei } \\
\text { 취오줌풀 } \\
\text { (5.15-6.15) }\end{array}$ & $\begin{array}{c}\text { Anemarrhena } \\
\text { asphodeloides } \\
\text { 지모 } \\
(6.15-7.5)\end{array}$ & $\begin{array}{l}\text { Stachys } \\
\text { macrantha } \\
\text { 'Superba' } \\
\text { 스타키스 } \\
\text { '수퍼바' } \\
\text { (6.15-7.15) }\end{array}$ & $\begin{array}{l}\text { Astilbe rubra } \\
\text { 노루오줌 } \\
(6.25-7.25)\end{array}$ & $\begin{array}{c}\text { Anemone } \\
\text { hupehensis var. } \\
\text { japonica } \\
\text { 대상화 } \\
(8.25-9.25)\end{array}$ & $\begin{array}{c}\text { Tricyrtis } \\
\text { dilatata } \\
\text { 뻐꾹나리 } \\
(8.15-9.25)\end{array}$ & $\begin{array}{c}\text { Bistorta } \\
\text { alopecuroides } \\
\text { 가는범꼬리 } \\
(6.5-7.5)\end{array}$ & $\begin{array}{c}\text { Symphytum } \\
\text { officinale } \\
\text { 컴프리 } \\
(5.15-6.5)\end{array}$ \\
\hline $\mathrm{L}$ & & & & $\begin{array}{c}\text { Veronicastrum } \\
\text { sibiricum } \\
\text { 냉초 } \\
(6.15-7.15)\end{array}$ & & & & \begin{tabular}{|c|} 
Digitalis \\
purpurea 'Pink \\
Champagne' \\
핑크샴페인 \\
디기탈리스 \\
$(5.25-6.15)$
\end{tabular} & & \\
\hline
\end{tabular}

Figure 7. Flower border layout $(10 \mathrm{~m} \times 3 \mathrm{~m})$ with pink flowers which have more than one month of flowering period. Each flower border is placed on either side of central path. Plants of same species are randomly placed in each $1 \mathrm{~m} \times 1$ $\mathrm{m}$ unit area. Each border was designed with large plants $(\mathrm{L}$ : over $120 \mathrm{~cm})$ in the back, medium plants (M: 60-120 $\mathrm{cm}$ ) in the middle, and small plant $(\mathrm{S}$ : below $60 \mathrm{~cm}$ ) toward the front of flower border. Only flower color, plant height and flowering period of perennials surveyed in this study were considered for this layout. Dates in parentheses represent flowering period of each species.

attributed to the fact that there are not enough herbaceous perennials with red and orange flowers or to the fact that they might not be preferred when planting. However, it seems to be very important to increase the number of red and orange flowers in order to make flower borders colorful (Billington, 2002; Bisgrove, 1992; Jekyll, 2001; Young, 2009).

\section{Blue and green}

There were not many herbaceous perennials with blue flowers (35 species) (Table 2), but still more than those with red and orange flowers. As one of the methods to make flower borders more colorful, two contrasting colors can be arranged such as red and blue, or yellow and blue. Likewise, it is necessary to secure more herbaceous perennials with blue flowers for flower borders. Veronica kiusiana var. glabrifolia of which flowering period is nearly 3 months seems to be very effective to make flower borders more colorful. Caryopteris incana was also included in the planned flower border below, since the semishrub is recognized as a perennial in the central region of Korea (Fig. 9).

Herbaceous perennials with green flowers are very rare, and thus green flowers, like silver flowers, are separately recognized only when highlighting the color of leaves, not the color of flowers. However, 7 species of perennials with green flowers were observed in the surveyed places including Arisaema amurense for. serratum, Arisaema ringens, Pinellia tripartita, Calamagrostis epigeios, Briza, Phalaris arundinacea var. picta and Alchemilla that is widely used in other countries (Table 2, Fig. 9). Since green is the color of leaves, the value of green flowers as a flower is not high, and thus they can be used to highlight their shapes or texture or can be mixed with those that have beautiful leaves. Winter 


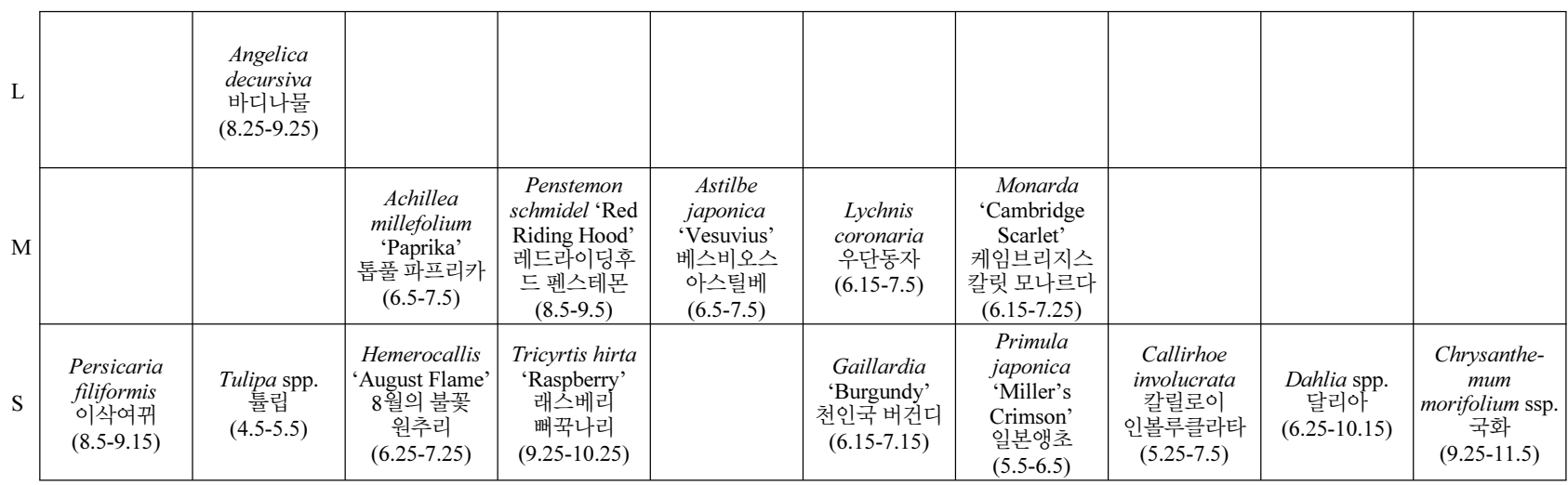

\begin{tabular}{|c|c|c|c|c|c|c|c|c|c|}
\hline \multicolumn{10}{|c|}{ Taut } \\
\hline $\mathrm{S}$ & $\begin{array}{c}\text { Chrysanthe } \\
\text {-mum } \\
\text { morifolium } \\
\text { 국화 } \\
(10.15-11.15)\end{array}$ & $\begin{array}{l}\text { Tulipa spp. } \\
\text { 튤립 } \\
(4.15-5.5)\end{array}$ & $\begin{array}{c}\text { Lilium } \\
\text { tsingtauense } \\
\text { 하늘말나리 } \\
(6.15-7.15)\end{array}$ & & $\begin{array}{l}\text { Gaillardia } \\
\text { aristata 'Bijou' } \\
\text { 천인국 비쥬 } \\
(6.5-8.5)\end{array}$ & & $\begin{array}{c}\text { Trollius } \\
\text { chinensis } \\
\text { 'Golden Queen' } \\
\text { 중국금매화 } \\
\text { 골든퀸 } \\
(5.15-6.15)\end{array}$ & $\begin{array}{c}\text { Lilium spp. } \\
\text { 백합 } \\
\text { (6.5-7.15) }\end{array}$ & $\begin{array}{l}\text { Lychnis } \\
\text { cognata } \\
\text { 동자꽃 } \\
(7.5-7.25)\end{array}$ \\
\hline $\mathrm{M}$ & & $\begin{array}{c}\text { Hemerocallis } \\
\text { fulva } \\
\text { 원추리 } \\
(7.5-7.25)\end{array}$ & & $\begin{array}{c}\text { Helenium } \\
\text { autumnale } \\
\text { 'Indian Summer’’ } \\
\text { 인디언섬머 } \\
\text { 헬레니움 } \\
(8.5-9.15) \\
\end{array}$ & $\begin{array}{c}\text { Lilium } \\
\text { callosum } \\
\text { 땅나리 } \\
(7.25-8.25)\end{array}$ & $\begin{array}{c}\text { Kniphofia } \\
\text { uvaria } \\
\text { 트리토마 } \\
(6.5-6.25)\end{array}$ & & $\begin{array}{c}\text { Belamcanda } \\
\text { chinensis } \\
\text { 범부채 } \\
(7.5-8.5)\end{array}$ & \\
\hline $\mathrm{L}$ & & & $\begin{array}{c}\text { Lilium } \\
\text { lancifolium } \\
\text { 참나리 } \\
(7.5-8.5)\end{array}$ & & $\begin{array}{c}\text { Rudbeckia } \\
\text { triloba } \\
\text { 'Prairie Glow' } \\
\text { 프레리 글로 } \\
\text { 루드베키아 } \\
\text { (7.5-8.15) }\end{array}$ & & & & \\
\hline
\end{tabular}

Figure 8. Flower border layout ( $10 \mathrm{~m} \times 3 \mathrm{~m}$ ) with red (upper) and orange (lower) flowers which have more than one month of flowering period. Each flower border is placed on either side of central path. Plants of same species are randomly placed in each $1 \mathrm{~m} \times 1 \mathrm{~m}$ unit area. Each border was designed with large plants (L: over $120 \mathrm{~cm})$ in the back, medium plants $(\mathrm{M}: 60-120 \mathrm{~cm})$ in the middle, and small plant $(\mathrm{S}$ : below $60 \mathrm{~cm}$ ) toward the front of flower border. Only flower color, plant height and flowering period of perennials surveyed in this study were considered for this layout. Dates in parentheses represent flowering period of each species.

evergreen perennials of which flowers do not stand out, but of which leaves are beautiful such as Dryopteris crassirhizoma, Ophiopogon jaburan 'Vittatus', Ardisia pusilla, Acorus gramineus and Acorus gramineus 'Ogon' can be matched with those with green flowers to create flower borders with a unique atmosphere. The name of evergreen perennials was marked in brackets for the green flower border in Fig. 9.

Of the three surveyed places, Hantaek Botanical Garden has many herbaceous flowering plants that form colonies. Some species were planted in several areas within the same place, but their plant height and flowering period were slightly different due to different environments including light, temperature, moisture and soil. Much more herbaceous perennials were observed in the surveyed places than those suggested in the basic planting plans, but plants that flower for less than one month such as Ligularia taquetii, Camassia and Lycoris radiata were excluded from this study despite their high ornamental value. However, they can be also used in gardens depending on their purposes.

Through the survey conducted in this study, various herbaceous perennials that grow in the central region of Korea and flower for over one month were identified and data on their flowering period and plant height were also collected. It is still necessary to further research factors, other than flower color, plant height and flowering period, such as visual elements (shape, texture, etc.), the relationship with growth environments (soil, etc.), optimal planting intervals, adaptability of different herbaceous perennials in the same space, and allelopathy between plants, in order to create flower beds or borders that show the beauty of herbaceous flowering plants which can be conveniently managed, or gardens of different styles. 


\begin{tabular}{|c|c|c|c|c|c|c|c|c|c|c|}
\hline $\mathrm{L}$ & & & $\begin{array}{c}\text { Anchusa azurea } \\
\text { 아주레아 } \\
\text { 앙쿠사 } \\
(5.25-6.15)\end{array}$ & & $\begin{array}{c}\text { Caryopteris } \\
\text { divaricata } \\
\text { 누린내풀 } \\
(8.25-9.15)\end{array}$ & & $\begin{array}{l}\text { Echinops } \\
\text { setifer } \\
\text { 절굿대 } \\
(8.15-9.25)\end{array}$ & $\begin{array}{c}\text { Nepeta sibirica } \\
\text { 시베리아 } \\
\text { 네페타 } \\
(6.15-7.5)\end{array}$ & & \\
\hline $\mathrm{M}$ & & $\begin{array}{c}\text { Veronica } \\
\text { kiusiana var. } \\
\text { glabrifolia } \\
\text { 큰산꼬리풀 } \\
(6.15-9.5)\end{array}$ & $\begin{array}{c}\text { Platycodon } \\
\text { grandiflorus } \\
\text { 'Hakone Blue' } \\
\text { 겹꽃도라지 } \\
(6.25-8.5)\end{array}$ & $\begin{array}{l}\text { Gentiana } \\
\text { scabra } \\
\text { 용담 } \\
(9.15-10.5)\end{array}$ & $\begin{array}{c}\text { Baptisia } \\
\text { australis } \\
\text { 밥티시아 } \\
(5.15-6.5)\end{array}$ & $\begin{array}{c}\text { Nepeta } \\
\text { subsessilis } \\
\text { 'Cool Cat' } \\
\text { 쿨캐트 네페타 } \\
(5.25-7.5)\end{array}$ & $\begin{array}{c}\text { Polemonium } \\
\text { boreale } \\
\text { 'Heavenly } \\
\text { Habit' 헤븐리 } \\
\text { 하빗 꽃고비 } \\
(5.15-6.25) \\
\end{array}$ & $\begin{array}{c}\text { Lobelia } \\
\text { siphilitica } \\
\text { 태청숫잔대 } \\
(8.5-9.15)\end{array}$ & $\begin{array}{c}\text { Eryngium } \\
\text { planum } \\
\text { 에린지움 } \\
(6.15-7.15)\end{array}$ & $\begin{array}{c}\text { Platycodon } \\
\text { grandiflorum } \\
\text { 도라지 } \\
(7.5-8.15)\end{array}$ \\
\hline $\mathrm{S}$ & $\begin{array}{c}\text { Salvia } \\
\text { nemorosa } \\
\text { 'Rhapsody in } \\
\text { Blue' 랩소디 } \\
\text { 인블루 살비아 } \\
(5.15-6.5)\end{array}$ & $\begin{array}{c}\text { Mertensia } \\
\text { virginica } \\
\text { 메르텐시아 } \\
(4.25-5.15)\end{array}$ & $\begin{array}{c}\text { Iris sanguinea } \\
\text { 붓꽃 } \\
(5.15-6.5)\end{array}$ & $\begin{array}{l}\text { Aquilegia } \\
\text { japonica } \\
\text { 하늘매발톱 } \\
(5.5-5.25)\end{array}$ & $\begin{array}{c}\text { Caryopteris } \\
\text { incana } \\
\text { 층꽃나무 } \\
(9.5-9.25)\end{array}$ & $\begin{array}{c}\text { Dracocephalum } \\
\text { argunense } \\
\text { 용머리 } \\
(5.25-6.25)\end{array}$ & $\begin{array}{c}\text { Muscari } \\
\text { armeniacum } \\
\text { 무스카리 } \\
(4.5-5.5)\end{array}$ & $\begin{array}{c}\text { Nepeta } \\
\text { faassenii } \\
\text { 'Auslese' } \\
\text { 오슬레세 } \\
\text { 네페타 } \\
(4.25-6.15)\end{array}$ & $\begin{array}{c}\text { Veronica } \\
\text { austriaca } \\
\text { subsp. vahlii } \\
\text { 발리 베로니카 } \\
\text { (5.25-6.15) }\end{array}$ & $\begin{array}{c}\text { Salvia } \\
\text { miltiorrhiza } \\
\text { 단삼 } \\
(5.25-6.15)\end{array}$ \\
\hline
\end{tabular}

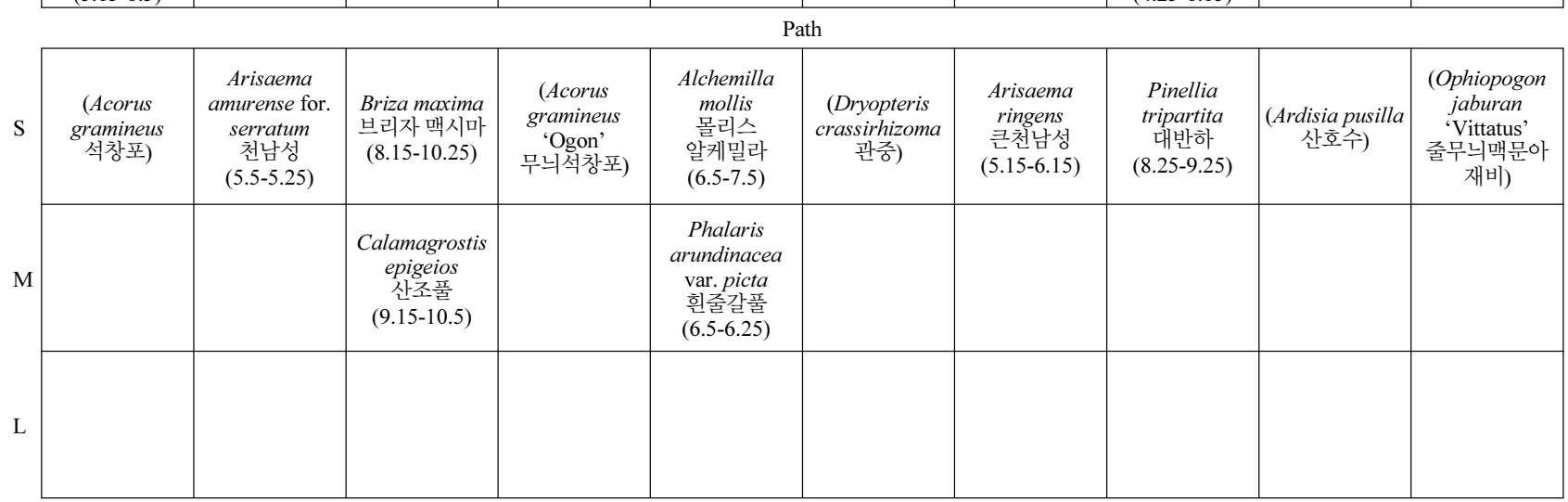

Figure 9. Flower border layout $(10 \mathrm{~m} \times 3 \mathrm{~m})$ with blue (upper) and green (lower) flowers which have more than one month of flowering period. Each flower border is placed on either side of central path. Plants of same species are randomly placed in each $1 \mathrm{~m} \times 1 \mathrm{~m}$ unit area. Each border was designed with large plants $(\mathrm{L}:$ over $120 \mathrm{~cm})$ in the back, medium plants (M: 60-120 cm) in the middle, and small plant $(\mathrm{S}$ : below $60 \mathrm{~cm}$ ) toward the front of flower border. Only flower color, plant height and flowering period of perennials surveyed in this study were considered for this layout. Dates in parentheses represent flowering period of each species.

\section{Conclusions}

With the aim of suggesting basic planting plans for flowers borders that show flowers throughout the year in the central region of Korea, the flowering period and plant height of herbaceous perennials planted in Hantaek Botanical Garden, Mulhyanggi Arboretum and Yonam College were surveyed on the 5th, 15th and 25th of every month in 2013, and on the 15 th of every month in 2014. The number of herbaceous perennials that flowered for over one month in Hantaek Botanical Garden, Mulhyanggi Arboretum and Yonam College was 278 (71.8\%), 81 (20.9\%), and 28 (7.2\%) respectively, a total of 387 species. They were divided by color as follows: white, 85 species (22.0\%); yellow, 79 species (20.4\%); purple, 73 species (18.9\%); pink, 72 species (18.6\%); blue, 35 species (9.0\%); red, 18 species (4.7\%); orange, 18 species (4.7\%); and green, 7 species $(1.8 \%)$. They were also divided by plant height as follows: large (over $120 \mathrm{~cm}), 56$ species $(14.5 \%)$; medium (60-120 cm), 99 species (25.6\%); and small (less than $60 \mathrm{~cm}$ ), a total of 232 species $(59.9 \%)$. In terms of flowering season, those that flowered in June accounted for the largest share (20.9\%), followed by July (17.2\%), May (16.2\%), August (12.3\%), September (11.7\%), April (9.5\%), October (6.5\%), November (2.1\%), December (0.2\%), and February $(0.2 \%)$.

In order to suggest planting plans for herbaceous perennials surveyed in this study, documents on the methods used to create flower borders in other countries were reviewed and photos taken when visiting the existing flower borders were analyzed. Based on the results, the size of $10 \mathrm{~m} \times 3 \mathrm{~m}$ was found to be suitable for flower borders. Of 9 flower colors of 
herbaceous flowering plants, 8 colors except silver were selected and 6 flower borders were suggested as follows: white; yellow; purple; pink; red and orange; and blue and green. For each flower border, only one species was planned to be planted in groups within an $1 \mathrm{~m} \times 1 \mathrm{~m}$ unit area, and the flower border was divided into three sections: large in the last row, medium in the middle row and small in the front row. The flowering period of the surveyed herbaceous perennials was marked on the map along with their name, and the plants were randomly laid out to create a flower border that shows flowers throughout the year. Since plants with white, yellow, purple and pink flowers that were frequently observed in the surveyed places were arranged on both sides of a road, and those with red and orange, and blue and green flowers that were less observed were arranged opposite to each other respectively. The unit areas that lack the plants of the plant height were left blank.

\section{References}

Billington, J. 2002. Color your garden. London: Quadrille Publishing Ltd.

Bisgrove, R. 1992. The Gardens of Gertrude Jekyll. London: Frances Lincoln.

Brickell, C (Ed.). 2002. The American Horticultural Society Encyclopedia of plants and flowers. London: DK.

Brickell, C (Ed.). 2007. The Royal Horticultural Society Encyclopedia of gardening. London: DK.

Brickell, C. (Ed.). 2010. The Royal Horticultural Society Encyclopedia of plants and flowers. London: DK.

Brickell, C. and H.M. Cathey (Eds.). 2004 The American Horticultural Society A-Z Encyclopedia of garden plants. London: DK.

Jekyll, G. 2001. Gertrude Jekyll's Colour Schemes for the Flower Garden. London: Frances Lincoln.

Jo, H.K. and T.H. Ahn. 2008. Differences in phenological phases of plants subsequent to microclimate change. Korean J. Environ. Ecol. 22(3):221-229.

Lord, T. and A. Lawson (Eds.), 2008. The Royal Horticultural Society Encyclopedia of planting combinations. London: Mitchell Beazley.

Oudolf, P. and H. Gerritsen. 2003. Planting the Natural Garden. Portland, OR: Timber Press.

Oudolf, P. and N. Kingsbury. 2005. Planting Design: Gardens in Time and Space. Portland, OR: Timber Press.

Oudolf, P. and N. Kingsbury. 2017. Planting: A New Perspective. Portland, OR: Timber Press.

Park, E.Y. 2010a. A study on the design method of flowering plants used in the English white gardens; -Focusing on Sissinghurst, Barrington Court built in the early 20th century-. J. Korean Inst. Tradit. Landsc. Archit. 28(4):144-153.

Park, E.Y. 2010b. A study on the method of color-centered planting design in the English gardens; -Focusing on Munstead Wood, Sissinghurst, Great Dixter, Hidcote Manner-. J. Korean Inst. Tradit. Landsc. Archit. 28(1):102-112.

Park, E.Y. and B.R. Yoo. 2004. A study on the method of Gertrude Jekyll's planting design. J. Korean Inst. Tradit. Landsc. Archit. 22(3):33-44.

Park, E.Y. and Y.R. Yoo. 2011. Texture characteristics of herbaceous plants used in relaxation gardens at the Chelsea Flower Show 2010. J. Korean Soc. People Plants Environ. 14(1):51-57.

Rice, G. (Ed.). 2006. The Royal Horticultural Society Encyclopedia of perennials. London: DK.

Sohn, K. 2012. Presentation of checklists for selection of herbaceous plants in garden design. J. Korean Soc. People Plants Environ. 15(1):47-60.

Sohn, K. 2013. Classification of Korean Garden Perennial Plants according to Growth Habit, Flower Color, Plant Height, and Flowering Month. J. Korean Soc. People Plants Environ. 16(6):383-400.

Young, C. (Ed.). 2009. Garden Design. London: DK. 